\title{
EWSR1 wt Allele
}

National Cancer Institute

\section{Source}

National Cancer Institute. EWSR1 wt Allele. NCI Thesaurus. Code C51239.

Human EWSR1 wild-type allele is located in the vicinity of 22q12.2 and is approximately $32 \mathrm{~kb}$ in length. This allele, which encodes RNA-binding protein EWS, may play a role in transcriptional repression or post-translational modification. An exact function has not been elucidated; however, mutations of the gene are known to cause Ewing sarcoma as well as neuroectodermal and various other tumors. The most common aberration that has been identified is a $\mathrm{t}(11 ; 22)(\mathrm{q} 24 ; \mathrm{q} 12)$ translocation. 